\title{
Spatial and Temporal Temperature Distributions in Municipal Solid Waste Landfills
}

\author{
James L. Hanson, Ph.D., P.E., M.ASCE'; Nazlı Yeşiller, Ph.D., A.M.ASCE²; and \\ Nicolas K. Oettle, A.M.ASCE ${ }^{3}$
}

\begin{abstract}
Long-term spatial and temporal variations in temperatures have been investigated in covers, wastes, and liners at four municipal solid waste landfills located in different climatic regions: Alaska, British Columbia, Michigan, and New Mexico. Temperatures were measured in wastes with a broad range of ages from newly placed to old (up to 40 years). The characteristic shape of waste temperature versus depth relationships consisted of a convex temperature profile with maximum temperatures observed at central locations within the middle third fraction of the depth of the waste mass. Lower temperatures were observed above and below this central zone, with seasonal fluctuations occurring near the surface and steady and elevated values (above mean annual earth temperature) near the base of the landfills. Heat gain and long-term temperatures were directly affected by placement temperatures. Sustained concave temperature profiles were observed for winter waste placement. The highest heat gain and resulting high temperatures were observed in Michigan followed by British Columbia, New Mexico, and Alaska. The high heat gain in Michigan was attributed to coupled precipitation/moisture content and waste density. The time-averaged waste temperature ranges were 0.9-33.0, 14.4-49.2, 14.8-55.6, and 20.5-33.6 ${ }^{\circ} \mathrm{C}$ in Alaska, British Columbia, Michigan, and New Mexico, respectively. Temperature increases occurred rapidly (over multiple years) in British Columbia and then dissipated for tens of years. Longer periods of temperature increase were observed at the other sites. Temperatures, temperature increases, and heat gain were higher during anaerobic decomposition of wastes than aerobic decomposition. A parametric study indicated that use of insulating materials over covers decreased temperature variations compared to uninsulated conditions for prevention of frost penetration or desiccation and for optimum methane oxidation. Overall, thermal regime of landfills is controlled by climatic and operational conditions.
\end{abstract}

\section{Introduction}

Significant amounts of heat are generated in municipal solid waste (MSW) landfills due to decomposition of organic wastes. Heat is a primary by-product of MSW landfills in addition to leachate and gas. Leachate and gas have been studied extensively, whereas less information is available on heat. Heat generation in wastes results in long-term elevated temperatures with respect to local air and ground temperatures in landfill systems (Yeşiller et al. 2005, 2008).

The maximum measured waste temperatures reported in literature varied from approximately 40 to $65^{\circ} \mathrm{C}$ for total waste heights

${ }^{1}$ Professor, Civil and Environmental Engineering Dept., California Polytechnic State Univ., San Luis Obispo, CA 93407 (corresponding author).

${ }^{2}$ Director, Global Waste Research Institute, California Polytechnic State Univ., San Luis Obispo, CA 93407.

${ }^{3}$ Staff Engineer, Geosyntec Consultants, Huntington Beach, CA of 20 to $60 \mathrm{~m}$ in the studies that were conducted over time. Relatively similar trends were observed in studies with one-time sampling events (Attal et al. 1992; Townsend et al. 1996; Zanetti et al. 1997; Gartung et al. 1999). As an exception, Koerner (2001) reported high short-term waste temperatures $\left(30^{\circ} \mathrm{C}\right.$ over initial two years) followed by low long-term temperatures $\left(10-20^{\circ} \mathrm{C}\right.$ over 9.5 years). For covers, Yeşiller et al. (2008) reported that temperatures typically followed seasonal trends with phase lag and amplitude decrement with depth. For bottom liner systems and bases of landfills, long-term temperatures between approximately 30 and over $50^{\circ} \mathrm{C}$ were observed. These liner temperatures were elevated (with respect to local air and ground temperatures), yet lower than the maximum waste temperatures (Dach and Jager 1995; Rowe 1998; Gartung et al. 1999; Yesiller and Hanson 2003; Yoshida and Rowe 2003; Koerner and Koerner 2006). Most of the temperature data provided in the literature to date have been either direct reports of temperature versus time trends at individual landfills with limited number of measurement locations and infrequent measurements (Lefebvre et al. 2000; Yoshida and Rowe 2003; Rowe 2005; Koerner and Koerner 2006) or modeling of heat transfer in landfills with little or no actual field temperature measurements (El-Fadel et al. 1996; Döll 1997).

Temperature and heat transfer influence biological, chemical, and geomechanical processes in wastes, liners, and covers. Opti- 
mum temperature ranges for gas production from waste decomposition were reported to be between 34 and $45^{\circ} \mathrm{C}$ from laboratory and field studies (DeWalle et al. 1978; Rees 1980a, b; Hartz et al. 1982; Mata-Alvarez and Martinez-Viturtia 1986). Significantly reduced gas production rates are expected at temperatures approximately below $20^{\circ} \mathrm{C}$ and above $75^{\circ} \mathrm{C}$ (Tchobanoglous et al. 1993). Engineering properties of wastes are affected by temperature (e.g., compressibility of wastes increased nearly twofold for a temperature change from 20 to $35^{\circ} \mathrm{C}$ in laboratory tests) (Lamothe and Edgers 1994).

High temperatures have adverse effects on liner systems including reduced lifetime of geosynthetics and desiccation of clay and geosynthetic clay liners (GCLs) that can cause development of secondary features (e.g., cracks) increasing leachate and gas transport (Rowe 2005). Desiccation of bottom liners is possible over the long term from heat generated in overlying wastes as demonstrated in modeling studies, laboratory experiments, and field tests by Döll (1997), Southen and Rowe (2005), and August et al. (1997), respectively. Similarly, desiccation of covers may occur due to heat generated in underlying wastes in combination with overlying climatic effects. Shrinkage of GCLs and seam separation in part due to thermal effects were reported in the field (K. Criley, personal communication, June 14, 2006). In addition, low temperatures and freeze-thaw cycles have adverse effects on liner systems (e.g., compromised hydraulic integrity of earthen barriers) (Benson and Othman 1993). Overall, temperature differentials across covers and bottom liners (for both exposed and waste-covered conditions) can cause thermally driven moisture flow and influence system performance.

Cover temperatures also affect oxidation of methane and emissions. Elevated temperatures result in increased oxidation of methane and reduced emissions. An optimum temperature range of $20-30^{\circ} \mathrm{C}$ was determined in laboratory incubation tests for methane oxidation in soils over a wide range of moisture contents (Boeckx et al. 1996). The thickness of biofilter (mixture of compost, wood fibers, and peat) required for $90 \%$ methane oxidation efficiency was $54 \%$ higher at $22^{\circ} \mathrm{C}$ than at $30^{\circ} \mathrm{C}$ with a maximum limit for optimum biocover operation of approximately $35^{\circ} \mathrm{C}$ based on laboratory tests (Streese-Kleeberg and Stegmann 2008). Methane flux from cover soils at landfills in Northern Europe decreased significantly in spring/summer months (with maximum soil cover temperatures of approximately $24-27^{\circ} \mathrm{C}$ ) compared to the measured values in fall/winter months (with minimum soil cover temperatures of approximately $0-10^{\circ} \mathrm{C}$ ) (Boeckx et al. 1996; Börjesson et al. 2001; Christophersen et al. 2001).

Detailed investigations of temperature distributions in a single landfill, comparisons of temperatures in multiple landfills, and identification of underlying fundamental trends in temperature distributions in landfills are limited. Results are provided in this paper for in situ temperatures and analytical investigation of heat transfer and resulting temperature distributions in MSW landfills. The analyses described herein were conducted as part of a longterm investigation of landfill thermal conditions.

\section{Measurement of Temperatures in Landfills}

The configuration of the sensors or the method of measurement may affect determination of temperatures in a landfill. Placement of sensors in rigid tubing (that has not been backfilled with soil or similar material) creates pathways for movement of gas or liquid near the sensors. This may cause convective heat flow along the

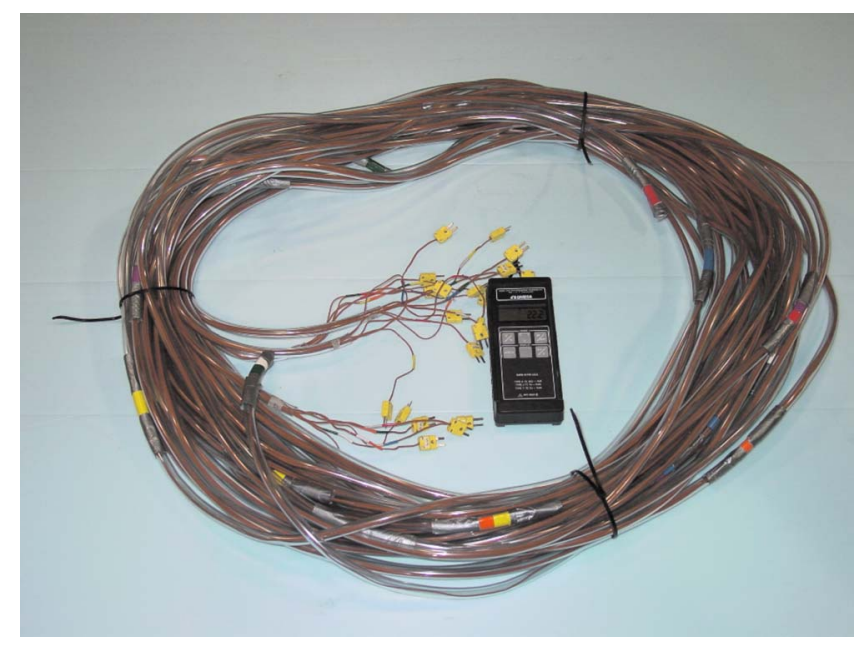

Fig. 1. Thermocouple array

length of the tubing resulting in unrepresentative measurements. Such fluid movement within the tube may also alter decomposition and degradation conditions near the sensors. Rigid tubing may be damaged by excessive or differential settlement of wastes. In addition, errors may be introduced if measurements are conducted during drilling operations. Heat generated during drilling may influence measured temperatures. Heat gain or loss may occur during removal of samples if samples are collected during drilling operations for measurement of temperatures at the ground surface.

The significant features of an effective temperature measurement system for landfills are durability of sensors against a corrosive aggressive environment, durability against mechanical stresses and movements, ability for prefabrication and transit, rapid deployment, feasible monitoring, ability for extension at a future date, and ability to provide representative in situ measurements. A wide variety of sensors has been used for temperature measurements in landfills including thermocouples [e.g., Yeşiller et al. (2005) and Koerner and Koerner (2006)], thermistors [e.g., Han et al. (2007)], and vibrating wire piezometers [e.g., Fleming et al. (1999) and Barone et al. (2000)]. The writers have determined that Type $\mathrm{K}$ thermocouples have high resistance to chemical environments and are well suited for landfill applications. Over $90 \%$ of intact sensors are still in service at the study sites since deployment between 5 and 10 years ago with a few complete arrays damaged/destroyed by heavy equipment during excavations associated with landfill maintenance and operation, unrelated to sensor type.

The writers have determined that placement of several thermocouple wires in flexible PVC tubing has numerous benefits. A thermocouple array constructed in this manner (Fig. 1) provides mechanical durability through an added layer of protection, an ability to construct before deployment (i.e., construct array off site), an assembled configuration that can be easily and economically transported (including air transit) to remote locations, a convenient means to hold multiple wires together, improved organization and rapid deployment for safety and operational concerns in a working landfill environment, conformance to uneven surfaces upon deployment or over time (i.e., in case of settlement), ability to be measured using either manual surveys or data loggers, minimal void space for convective heat transfer within the tube and even less space subsequent to application of over- 
Table 1. Climatic and Operational Statistics [from Yeşiller et al. (2005) and Oettle et al. (2008)]

\begin{tabular}{|c|c|c|c|c|}
\hline Parameter & Alaska $^{\mathrm{a}}$ & British Columbia $^{\mathrm{b}}$ & Michigan $^{a}$ & New Mexico ${ }^{a}$ \\
\hline Climate description $^{\mathrm{c}}$ & Oceanic boreal & Woodland oceanic & Humid continental temperate & Semidesert \\
\hline Average air $T_{h i g h}\left({ }^{\circ} \mathrm{C}\right)$ & 6.2 & 13.5 & 14.7 & 25.1 \\
\hline Average air $T_{\text {low }}\left({ }^{\circ} \mathrm{C}\right)$ & -1.5 & 6.1 & 5 & 11.2 \\
\hline Average air $T\left({ }^{\circ} \mathrm{C}\right)$ & 2.3 & 9.9 & 9.8 & 18.2 \\
\hline Mean surface $T\left({ }^{\circ} \mathrm{C}\right)$ & 6.9 & 13.0 & 11.8 & 19.8 \\
\hline Surface $T$ amplitude $\left({ }^{\circ} \mathrm{C}\right)$ & 14.3 & 11.6 & 12.0 & 12.0 \\
\hline Annual normal precipitation (mm) & 408 & 1,167 & 835 & 240 \\
\hline Annual normal snowfall (mm) & 1,793 & 549 & 1,046 & 135 \\
\hline Mean annual earth temperature $\left({ }^{\circ} \mathrm{C}\right)$ & 6.0 & 11.5 & 11.7 & 20.0 \\
\hline Design waste placement area (ha) & 67 & 225 & 65 & 79 \\
\hline Average waste intake ( $t$ /year) & 317,000 & 390,000 & 965,000 & 114,000 \\
\hline Average waste column height (m) & 28.7 & 11.3 & 25.2 & 13.2 \\
\hline Overall total unit weight $\left(\mathrm{kN} / \mathrm{m}^{3}\right)$ & $5-6$ & $8.5-10$ & $9-13$ & $5-8$ \\
\hline Primary daily cover & Soil & Soil and tarp & Soil and demolition waste & Soil \\
\hline
\end{tabular}

${ }^{\mathrm{a}}$ From National Climatic Data Center (NCDC) (2006).

${ }^{\mathrm{b}}$ From Meteorological Service of Canada (MSC) (2007).

${ }^{\mathrm{c}}$ Based on Landsberg et al. (1966).

burden stresses after deployment, and ability to reach thermal equilibrium.

In general, the arrays are placed either in a trench (horizontal array) or a borehole (vertical array) and the air space is backfilled with waste or soil as appropriate. Particular attention is paid to sealing locations where the arrays exit a landfill system. The writers have been obtaining temperature measurements using handheld digital thermometers. This approach is labor intensive, however, is economically feasible at sites with multiple sensor array locations that would each require a dedicated data logger for automated data collection. Rotary selection switches can be used with the system to expedite manual field temperature measurements. Overall, determination of temperatures using Type K thermocouples in flexible sensor arrays within well-sealed pathways has been demonstrated to be effective. Temperature measurements using sensors placed in rigid tubing, on excavated samples, or during drilling generally are not recommended.

\section{Field Test Program}

\section{Field Test Sites}

Temperature data have been obtained at four MSW landfills located in different climatic regions in North America: Alaska, British Columbia, Michigan, and New Mexico. The facilities located in Alaska, Michigan, and New Mexico are Subtitle D landfills (e-CFR 2009), whereas the landfill in British Columbia contains a base support/liner system and a gravity-flow leachate collection system. Landfills located in Alaska, British Columbia, and Michigan have active gas collection systems, whereas the site in New Mexico does not yet have a gas collection system. The degree of waste compaction at the sites was dependent on both the compactive effort applied to the wastes (a function of waste intake versus number of compactors) and the as-received moisture contents of the wastes (for which direct measurements at the test sites were not available but were observed to be generally correlated to sitespecific precipitation). Daily cover at all sites was composed of soil or reused/recycled materials (e.g., shredded rubber tire, wood chips, construction and demolition waste). Slurry or foam based alternative daily covers were not used at any of the sites. Leachate recirculation was used occasionally in Michigan and Alaska, but the applications were intermittent and seasonally based and not continual or system wide. Details for climatic and operational conditions at the sites are provided in Table 1. Additional operational details for the sites were provided by Yeşiller et al. (2005).

\section{Configuration of Sensor Arrays}

Temperatures were measured throughout the landfills including bottom liner, waste mass, cover, and perimeter control locations (in native subgrade soils away from the zone of influence of the waste mass). Temperatures were measured using Type $\mathrm{K}$ thermocouples deployed in custom-fabricated arrays (Fig. 1). The arrays ranged in length between 1 and $60 \mathrm{~m}$ for vertical installations (installed in boreholes through covers and wastes and at control locations) and between 150 and $200 \mathrm{~m}$ for horizontal installations (installed in trenches within liners, covers, and wastes). Additional details for array configurations are provided by Hanson et al. (2005) and Yeșiller et al. (2005, 2008). Vertical installations were made subsequent to waste placement and allowed for determination of temperature variations with depth and waste age at a given location. Horizontal installations were made during waste placement or during liner/cover construction and allowed for determination of temperatures with location at a given depth and single waste age. Over 700 temperature sensors were installed at the combined sites. Measurements were taken on a weekly basis at each site. In addition, gas composition was measured in wastes using monthly samples collected from the same locations as the temperature sensors using custom-fabricated sampling arrays (Hanson et al. 2005). The total monitoring periods have spanned 5-10 years.

\section{Results and Discussion}

\section{Characteristic Landfill Temperature Profiles}

The data from the test sites were used to investigate characteristic landfill temperature profiles with depth. The effects of placement temperature and waste age on the resulting temperature profiles were determined. Year-to-year comparisons were made for temperature versus depth data at the test sites. 


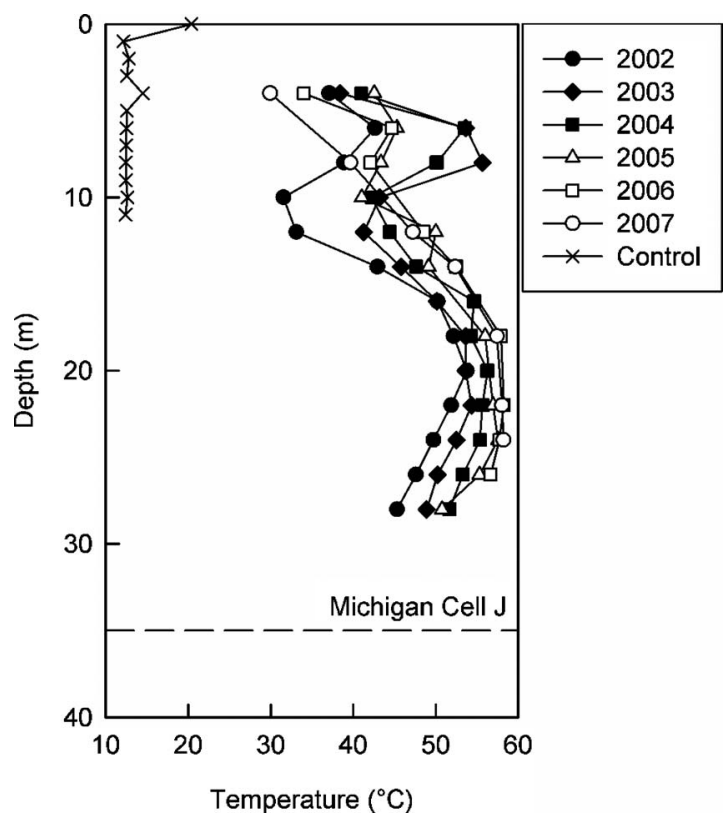

Fig. 2. Example of temperature profiles at Michigan with time

The characteristic shape of waste temperature versus depth relationships consists of a convex temperature profile with maximum temperatures near middepths of a landfill and lower temperatures both above and below this central zone. The locus of maximum temperature is modified with time as heat is generated, redistributed, and dissipated throughout the landfill system. Temperature profiles are presented in Fig. 2 for a cell in Michigan that was filled with wastes between 1999 and 2001. On all temperature versus depth plots, horizontal dashed lines indicate the elevation of the bottom liner system. Data provided in Fig. 2 represent average temperatures for a year at each depth. Waste temperatures generally increased with time at all depths. The wastes at depth were placed during warm seasons while the shallower wastes

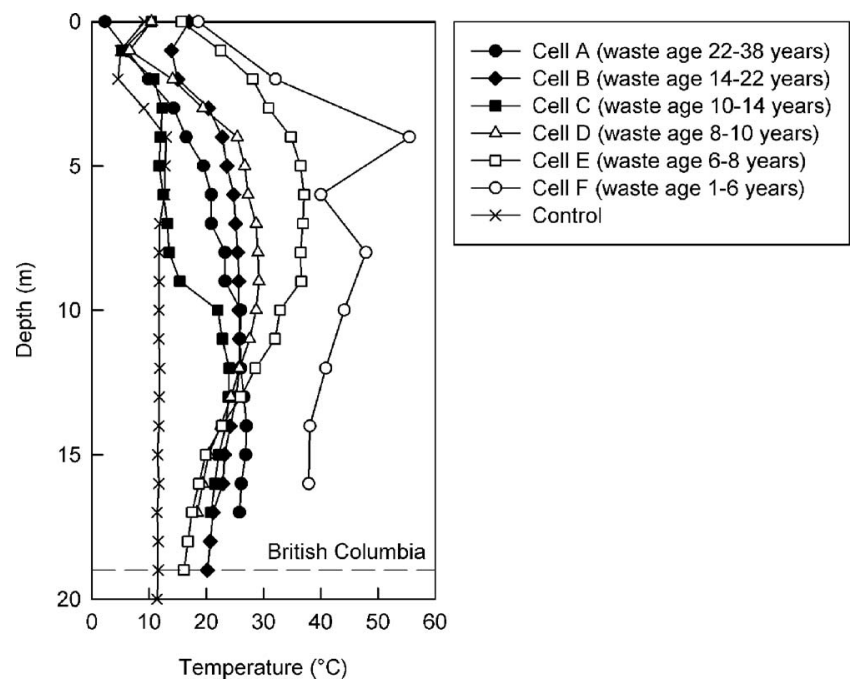

Fig. 4. Temperature profiles for variable waste age

were placed in cold seasons. The concave profiles at shallow depths resulted from the cold placement temperatures. The maximum temperatures occurred at approximately the same depth over time.

Examples of temperature profiles are presented in Figs. 3 and 4 for British Columbia. Tautochrones (instantaneous temperature profiles on a specific date) are presented in these figures for February survey dates. Redistribution of heat is presented in Fig. 3 for Cell D (approximately 9-12-year waste age) and Cell E (approximately $7-10$-year waste age). In both cells, waste temperatures decreased with time. At Cell E, a significant localization of elevated temperature zone was observed over the three-year period presented in Fig. 3, whereas at Cell D, a global decrease in temperature was observed with a less pronounced localization. In both cases, the locus of peak temperature occurred at greater depths with time. Tautochrones for vertical arrays were compared
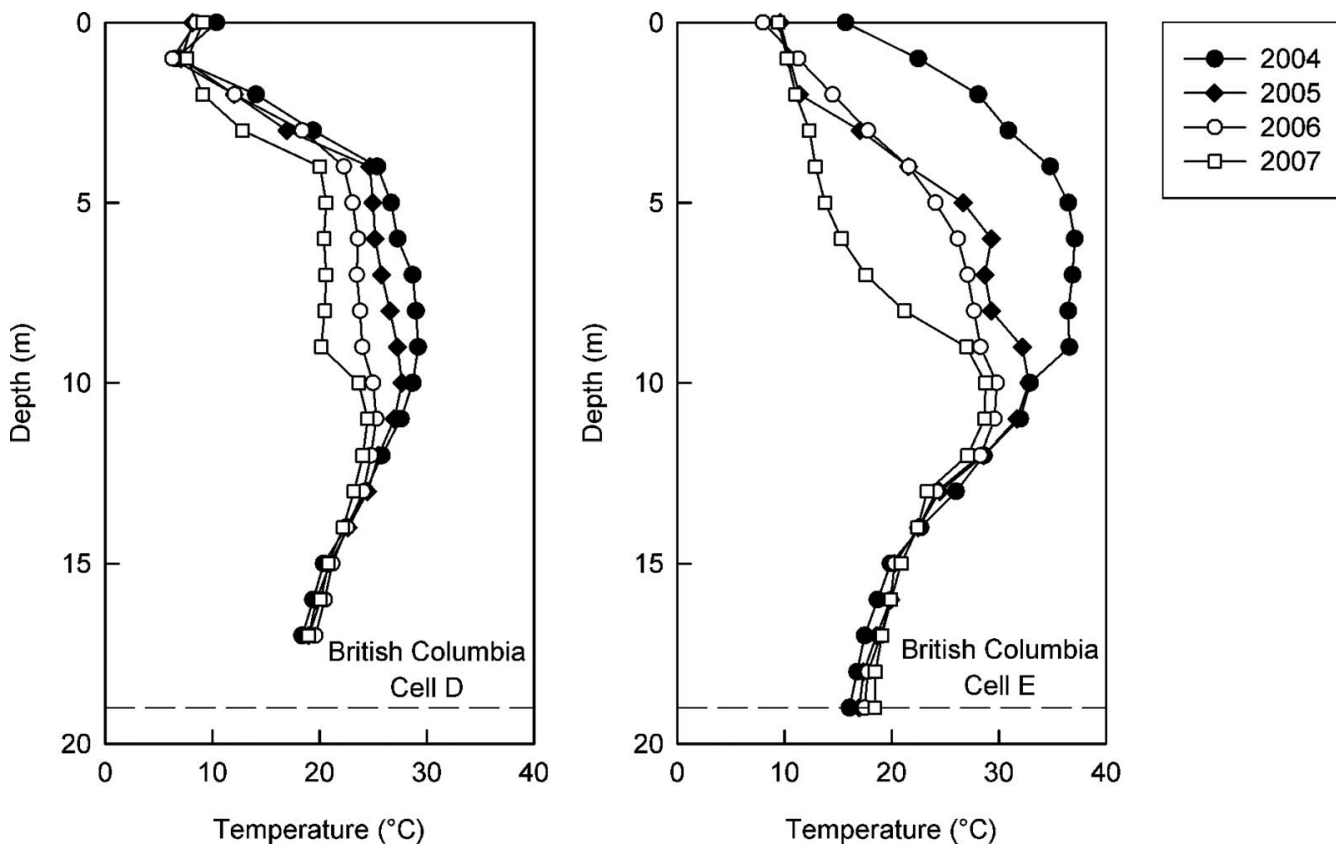

Fig. 3. Temperature profiles at British Columbia with time 


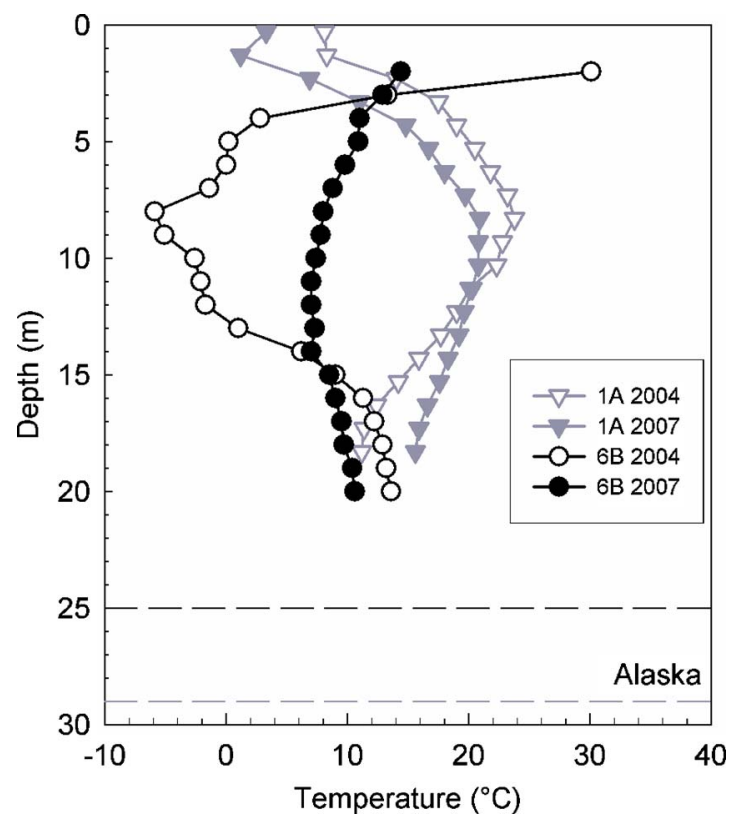

Fig. 5. Comparison of temperature profiles for frozen and unfrozen waste placement conditions in Alaska

for six different cells with a broad range of waste ages (one year for Cell F and 38 years for Cell A) in Fig. 4. The temperature profiles monotonically shifted to the left (i.e., to lower temperatures) with age with the exception of Cell C. Residual heat gain remained at depth for all cells. Temperatures near the surface were similar to unheated control ground temperatures. Heat generation occurred rapidly in British Columbia due to high precipitation (Yeşiller et al. 2005; Hanson et al. 2008) and the heat dissipated for a period of decades.

The maximum temperatures increased after waste placement and decreased over the long term as landfill temperatures slowly returned to ambient ground temperature conditions. The average rates of peak temperature increase were approximately $1.5-2.5^{\circ} \mathrm{C} /$ year for eight years (and continuing) after an initial period of two to four years of limited temperature change in Alaska, $5-9^{\circ} \mathrm{C} /$ year for four years in British Columbia, $1-3^{\circ} \mathrm{C} /$ year over the first $5-10$ years after waste placement in Michigan, and $0.3^{\circ} \mathrm{C} /$ year for a decade (and continuing) after waste placement in New Mexico. High waste moisture conditions (as inferred from precipitation) resulted in rapid temperature increases. Long-term postpeak trends were obtained from the British Columbia site for waste ages up to 38 years. The data indicated $1-5^{\circ} \mathrm{C}$ /year decrease over the years following peak temperatures and $0.2-0.3^{\circ} \mathrm{C} /$ year decrease decades after peak temperatures.

Examples of temperature profiles in Alaska are presented in Fig. 5 as a function of initial waste placement conditions. Tautochrones are presented in this figure for May survey dates. In Cell 1 , the temperature profile exhibited a convex shape. Waste was placed during various seasons over multiple years and the age of the wastes was one to five years in 2004. Heat was both generated and redistributed over the three-year period presented in the figure. Temperatures decreased at shallow depths and increased at greater depths. In Cell 6, a concave temperature profile was observed that resulted from placement of a 7-m-thick layer of frozen waste in winter. The waste ranged from zero to two years old in 2004. The frozen waste caused long-standing low temperatures that prevented heat generation and were not overcome by overlying and underlying heat production. Frozen conditions remained for two years at depth and even after three years the temperature profile remained concave with minimum temperatures at middepth (Fig. 5).

Effects of initial waste placement temperature on resulting waste temperatures and underlying liner temperatures are further demonstrated in Fig. 6. Long-term waste and liner temperatures were directly correlated to temperatures of the wastes at the time of placement. Long-term temperatures increased with increasing placement temperatures. The rate of temperature increase (i.e., slope of temperature versus time plot) was generally similar for different waste placement temperatures at a given site. Therefore, warmer placement conditions resulted in warmer stable long-term temperatures as shown for Michigan (W1-W6 and L1-L3) and Alaska (W7 and W8). For the case of frozen waste placement conditions in Alaska (W7 and W8), a delay in heat gain was observed that was attributed to latent heat effects. Sensor W8 had a longer thawing period than W7, as it was located near the center of the frozen band of waste. Waste placement sequences can be modified at a landfill for obtaining target temperature ranges in wastes (e.g., for optimal gas production) and liners (e.g., to prevent desiccation).

A schematic depiction of a typical temperature versus depth envelope for an MSW landfill is presented in Fig. 7. A representative temperature versus depth envelope is also provided for unheated ground for comparison. Landfill temperatures are in general higher than the unheated ground temperatures due to the heat generated by the wastes. Global thermal gradient $\left(i_{g}\right)$ represents the slope of the average temperature versus depth relationship within the landfill (dashed gray line in Fig. 7). The nearsurface average global thermal gradient was determined to be
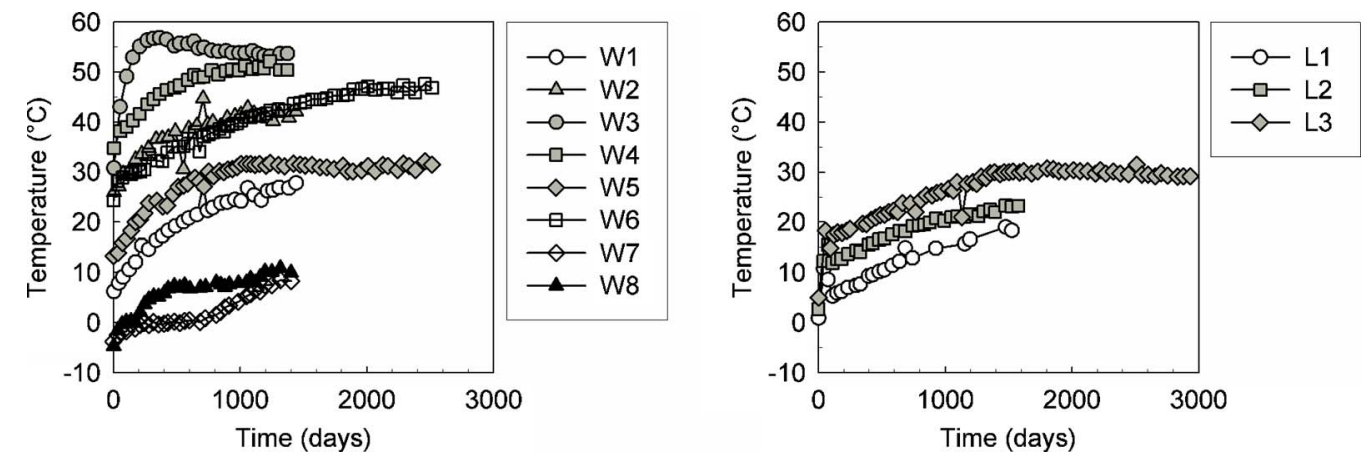

Fig. 6. Effect of waste placement temperature 


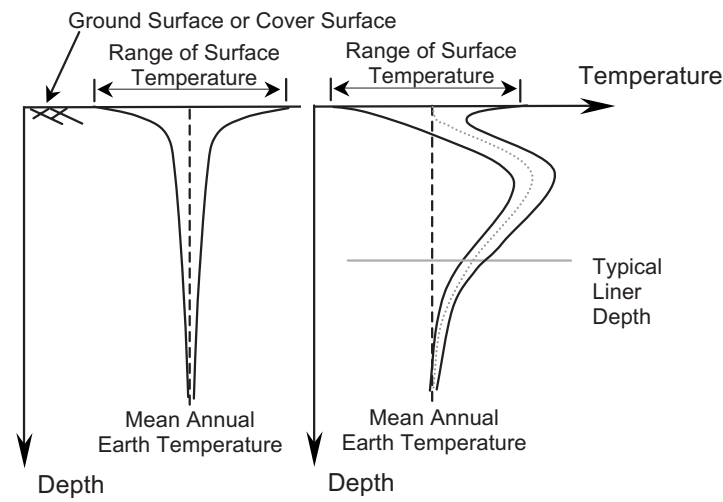

Fig. 7. Schematic temperature envelopes for soil and for a landfill

$2{ }^{\circ} \mathrm{C} / \mathrm{m}$ based on the analysis of the cover system data at the four instrumented sites (Yeşiller et al. 2008). At greater depths, the average global thermal gradient ranged from 2 to $6^{\circ} \mathrm{C} / \mathrm{m}$ as waste temperatures approached peak temperature conditions at central locations within the middle third fraction of the depth of the waste mass. Below these elevations, average $i_{g}$ ranged from -1 to $-2^{\circ} \mathrm{C} / \mathrm{m}$.

The liner temperatures were higher than mean annual earth temperatures and the maximum steady temperatures occurred near the midpoint length of the cell floors. The minimum waste and liner temperatures occurred near the top surface and perimeter edge of the cells, respectively. The cover temperatures varied seasonally with phase lag and amplitude decrement with respect to air temperatures. Limiting (maximum and minimum) temperatures are presented for covers, wastes, and bottom liners for the sites in Table 2. The data represent time-averaged values over the entire study period for each site as obtained from a single sensor. These data can be used as guidelines for service temperatures for various components of landfills under similar climatic conditions for determining engineering performance. Gas production, service lifetime of soil and geosynthetic barrier materials, and efficiency of methane oxidation in covers can be estimated for realistic field conditions using the provided temperature ranges and thermal gradients.

\section{Heat Gain in Wastes}

Analyses were conducted to determine the heat gain in the wastes. The average temperature differential of the wastes (as compared to unheated conditions) was calculated. The average temperature differential at a given depth was calculated as the time-averaged difference between the waste temperature versus time curve and the equivalent unheated waste temperature versus time curve (Yeşiller et al. 2005). The unheated conditions were estimated using conventional earth temperature theory (Carslaw and Jaeger

Table 2. Limiting Temperatures Observed in Landfills

\begin{tabular}{lcccc}
\hline Parameter & Alaska & British Columbia & Michigan & New Mexico \\
\hline$T_{\text {min waste }}\left({ }^{\circ} \mathrm{C}\right)$ & 0.9 & 13.1 & 14.8 & 20.5 \\
$T_{\text {max waste }}\left({ }^{\circ} \mathrm{C}\right)$ & 33.0 & 49.2 & 55.6 & 33.6 \\
$T_{\text {min liner }}\left({ }^{\circ} \mathrm{C}\right)$ & NA & 17.5 & 12.6 & 19.0 \\
$T_{\text {max liner }}\left({ }^{\circ} \mathrm{C}\right)$ & NA & 37.2 & 26.2 & 29.0 \\
$T_{\text {min cover }}\left({ }^{\circ} \mathrm{C}\right)^{\text {a }}$ & 4.8 & 7.7 & 4.1 & 12.6 \\
$T_{\text {max cover }}\left({ }^{\circ} \mathrm{C}\right)$ & 23.6 & 24.3 & 22.3 & 30.8 \\
\hline
\end{tabular}

Note: $\mathrm{NA}=$ not available.

${ }^{\mathrm{a}}$ Data provided for 1-m depth, adapted from Yeşiller et al. (2008).
Table 3. Thermal and Material Properties (from Hanson et al. 2008)

\begin{tabular}{lcccc}
\hline Parameter & Alaska & $\begin{array}{c}\text { British } \\
\text { Columbia }\end{array}$ & Michigan & New Mexico \\
\hline$\gamma_{\text {waste }}\left(\mathrm{kN} / \mathrm{m}^{3}\right)$ & 5.2 & 9.8 & 9.8 & 7.4 \\
$k_{t \text { waste }}(\mathrm{W} / \mathrm{mK})$ & 0.3 & 1.5 & 1.0 & 0.6 \\
$C_{\text {waste }}\left(\mathrm{kJ} / \mathrm{m}^{3} \mathrm{~K}\right)$ & 1,000 & 2,200 & 2,000 & 1,200 \\
$\alpha_{\text {waste }}\left(\mathrm{m}^{2} / \mathrm{s}\right)$ & $3.0 \times 10^{-7}$ & $7.0 \times 10^{-7}$ & $5.0 \times 10^{-7}$ & $5.0 \times 10^{-7}$ \\
$\gamma_{\text {soil }}\left(\mathrm{kN} / \mathrm{m}^{3}\right)$ & 21.0 & 17.7 & 20.5 & 16.7 \\
$k_{\text {t soil }}\left(\mathrm{W} / \mathrm{mK}^{3}\right)$ & 2.4 & 1.0 & 2.5 & 0.7 \\
$C_{\text {soil }}\left(\mathrm{kJ} / \mathrm{m}^{3} \mathrm{~K}\right)$ & 1,800 & 3,100 & 2,800 & 1,300 \\
$\alpha_{\text {soil }}\left(\mathrm{m}^{2} / \mathrm{s}\right)$ & $1.3 \times 10^{-6}$ & $3.3 \times 10^{-7}$ & $9.0 \times 10^{-7}$ & $4.9 \times 10^{-7}$ \\
\hline
\end{tabular}

Note: $\gamma=$ total unit weight; $k_{t}=$ thermal conductivity; $C=$ volumetric heat capacity; and $\alpha=$ thermal diffusivity.

1959) with representative thermal properties for wastes (Table 3 ). The average temperature differential represents heat gain of the waste solely due to biological decomposition. This analysis effectively filters out both seasonal temperature variations and differences in ambient average ground temperatures between the sites. The relative position of maximum temperature differential was determined using normalized depth for the landfill profiles (zero corresponding to surface and 1.0 corresponding to bottom liner location) to compare the general patterns for temperature profiles, independent of the actual depth of the waste mass.

Variations in average temperature differential for each site are presented in Fig. 8. The arrays selected for this analysis extended through the greatest fraction of depth of wastes and had comparable waste ages (approximately seven years). The highest average temperature differential was observed in Michigan due to the coupled high precipitation/moisture conditions and high waste density, whereas the lowest differential was observed in New Mexico due to the dry climate and low waste density. Even though the highest heat generation (i.e., energy) was observed in British Columbia, the highest heat gain (i.e., magnitude of temperature change) did not occur at this site due to the comparatively high heat capacity of the wet wastes (Table 3). Also contributing is the lower dry density of the wastes in British Columbia (as inferred from Table 1). The maximum temperatures for Alaska and British Columbia were similar, however, the temperatures in Alaska are increasing from previously cooler tem-

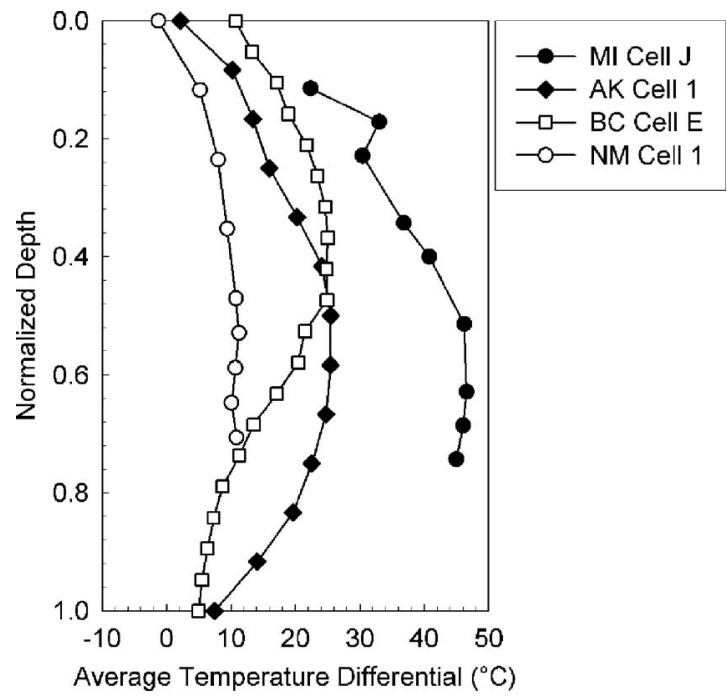

Fig. 8. Variation in average temperature differential at all sites 


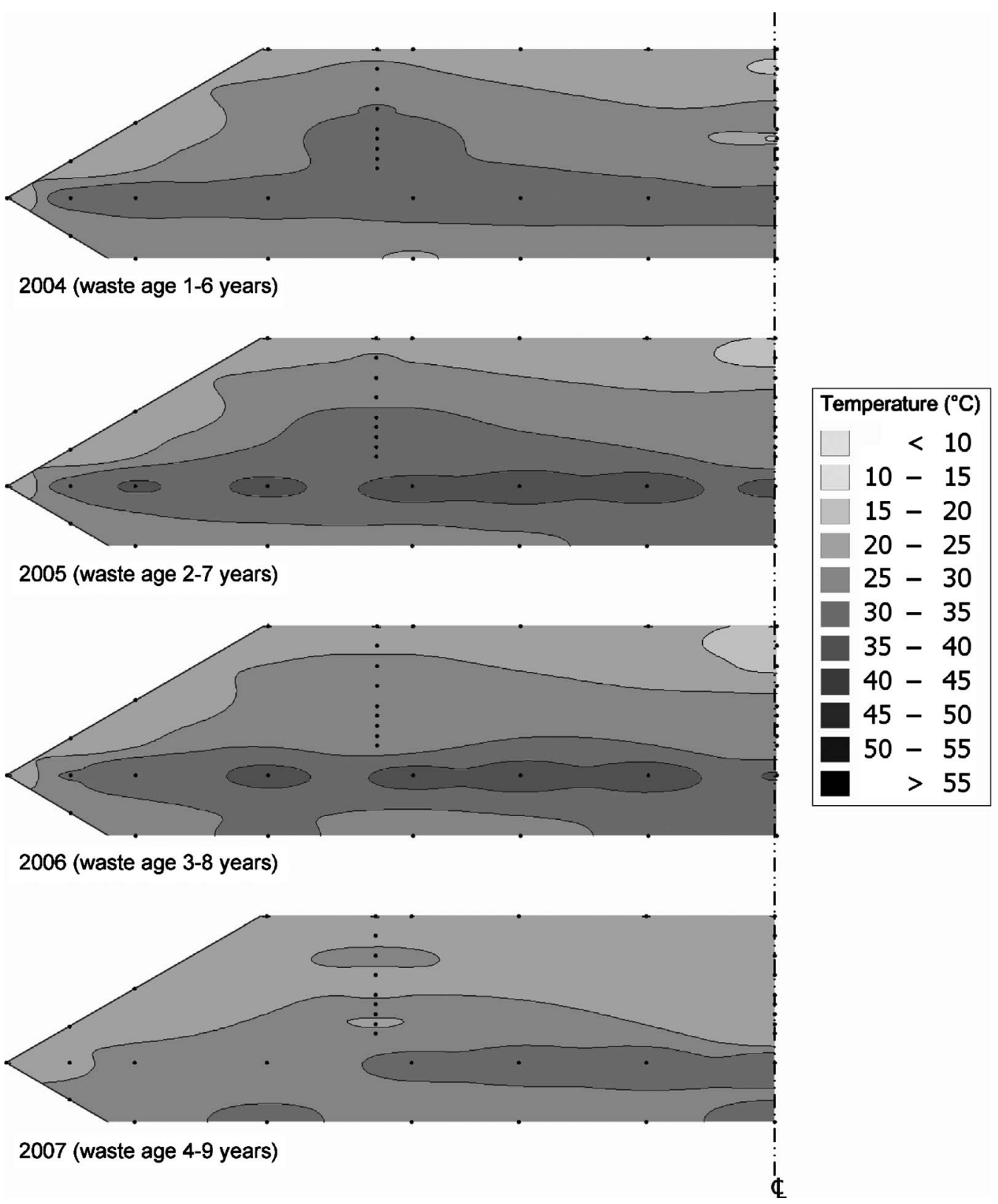

Fig. 9. Temperature contour maps for New Mexico

peratures whereas the temperatures in British Columbia are decreasing from previously higher temperatures. The delay in heat gain in Alaska is attributed to dry conditions and cool ambient temperatures. The rapid heat gain (i.e., rate of temperature change) in British Columbia resulted from enhanced microbial activity associated with high precipitation and wet wastes. Further description of mechanisms of heat generation and heat gain in wastes is provided by Yeşiller et al. (2005) and Hanson et al. (2008).

\section{2-D Distributions of Temperatures}

Contour maps of temperature were developed for Michigan and New Mexico, sites for which high spatial resolution in data was present. Maps are presented for multiple years of data to demonstrate variations in temperatures with time. Year-to-year comparisons are presented as temperature contour maps for superimposed data from two adjacent cells (Cells 1 and 2) in New Mexico (Fig. 9) and a single cell (Cell D) in Michigan (Fig. 10).
In New Mexico, temperatures increased slightly and generally stabilized with time (Fig. 9). In Michigan, a greater increase in temperatures and expansion of elevated temperatures at the central elevations of the cell were observed (Fig. 10). The higher temperatures in Michigan resulted from the combined effects of climatic and operational conditions including high precipitation/ moisture conditions and high waste density.

The spatial distributions of the waste temperatures were mainly affected by climatic and subgrade conditions. In particular, the difference between observed trends at New Mexico and Michigan was attributed to differential between peak waste temperatures and ambient mean annual earth temperatures at depth as well as the thermal properties of subgrade soils. In New Mexico the peak waste temperatures were approximately $35^{\circ} \mathrm{C}$ and the mean annual earth temperature was approximately $20^{\circ} \mathrm{C}$, whereas in Michigan the peak waste temperatures were approximately $55^{\circ} \mathrm{C}$ and the mean annual earth temperature was approximately 


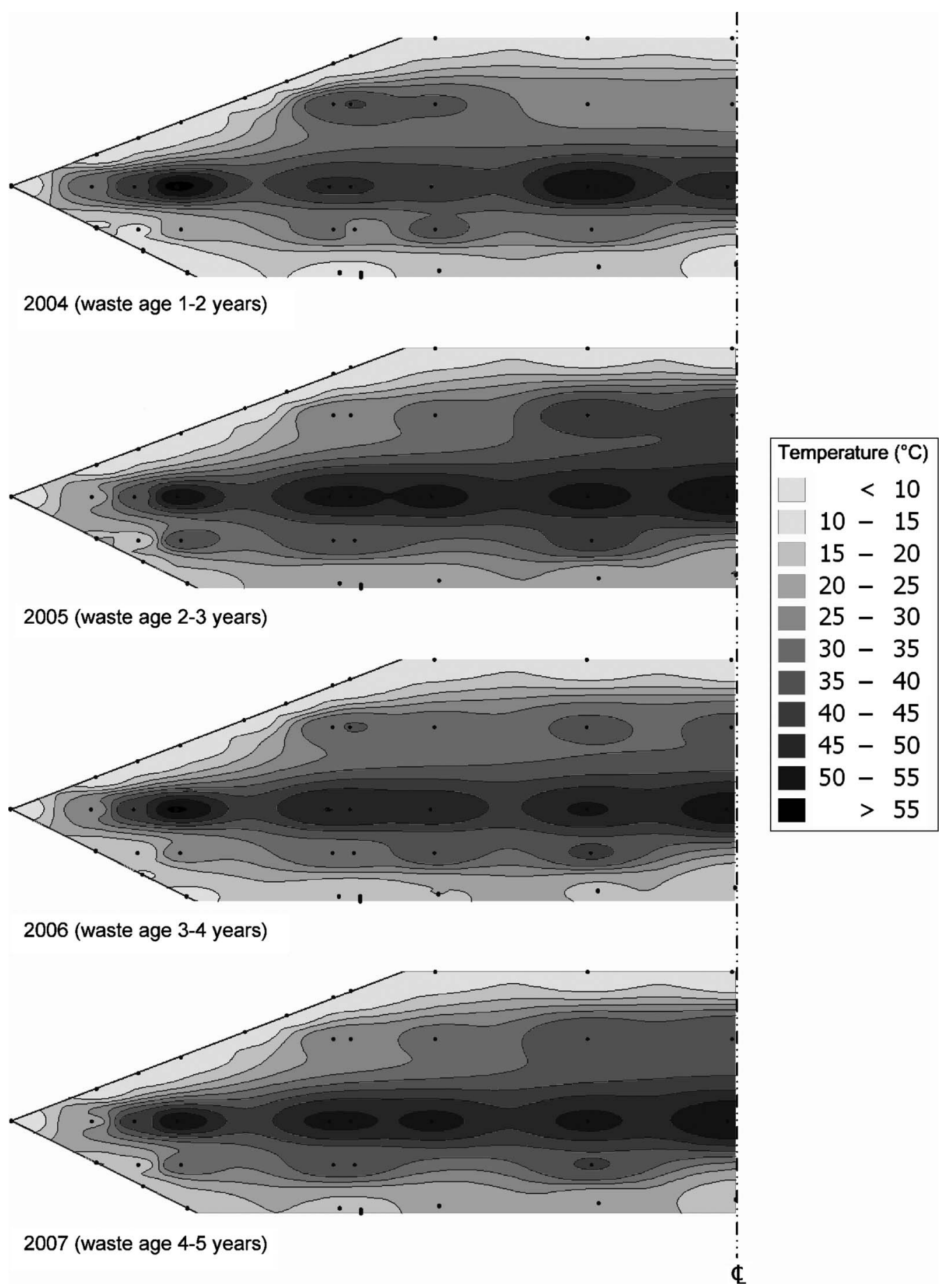

Fig. 10. Temperature contour maps for Michigan

$12^{\circ} \mathrm{C}$. The larger contrast between waste and ambient temperatures in Michigan produced higher thermal gradients (more contour lines in Fig. 10) than New Mexico (Fig. 9). In addition, the thermal diffusivity of the subgrade at Michigan was higher than the diffusivity in New Mexico, which provided a more effective heat sink. Secondary climatic effects may have contributed to the differences between the sites with snow cover in Michigan providing insulation for portions of the year and heavy winds in New Mexico providing high convective heat losses at the ground surface. All of these effects resulted in a deeper central zone of maximum temperatures in New Mexico than in Michigan. Inte- grated analyses of landfill systems with local climatic and subgrade conditions are required to obtain representative system thermal behavior.

\section{Waste Decomposition and Thermal Conditions}

Waste temperatures at the study sites started to increase upon placement and continued to increase over time. Temperatures increased for multiple years, remained at high levels for extended periods, and then decreased over long periods. Analysis of gas compositions indicated that aerobic conditions existed in the 


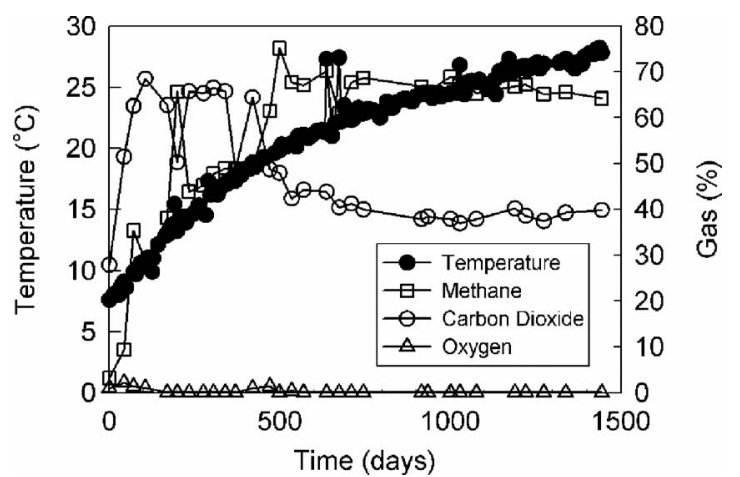

Fig. 11. Variations in waste temperatures and gas compositions with time

waste masses for generally weeks to several months based on results from all four sites. Transition to anaerobic conditions occurred over several months with anaerobic conditions prevailing for the remainder of the study periods. Temperatures of wastes increased during aerobic, transition, and subsequent anaerobic phases of decomposition. A representative example of variations in waste temperatures and gas composition with time for the Michigan site is presented in Fig. 11. The reported trend of early temperature peaks in aerobic phase followed by decreases and resulting low temperatures during anaerobic phase (Farquhar and Rovers 1973; Zanetti et al. 1997; Lefebvre et al. 2000) was not observed in this study. Seasonal variations may have affected the analysis of data at shallow depths in the studies reported in literature. Sustained high temperatures were measured in wastes under anaerobic conditions in the long term in all of the landfills investigated in this study. Similarly, significant heat gain occurred under anaerobic conditions and heat gain for anaerobic conditions was higher than heat gain during aerobic decomposition (Yeşiller et al. 2005). Overall, higher temperatures, temperature increases, and heat gain occurred during anaerobic decomposition of wastes than under aerobic conditions.

\section{Analytical Investigation}

Temperature variations in covers and exposed bottom liners (subsequent to construction and prior to waste placement) were further investigated using an analytical approach. Insulating layers can be used over landfill covers or liners left exposed for extended periods of time to maintain effective temperature ranges for engineering performance including preventing frost penetration, preventing desiccation, and maintaining cover temperatures that are conducive to optimal methane oxidation. Detailed analysis of temperature distributions in cover systems was conducted to evaluate the effect of variable depth of insulating materials (e.g., shredded rubber tire, wood chips, or plastic chips) over the cover. Temperature envelopes were developed for variable types of insulating materials (by varying thermal diffusivity, $\alpha$ ), variable thicknesses of insulating materials, and variable climatic conditions using seasonal earth temperature theory [Carslaw and Jaeger 1959; Oak Ridge National Laboratory (ORNL) 1981]. A sitespecific sinusoidal function was applied at the surface to represent seasonal surface temperature variations at each site (Table 1). The theory was modified for landfill cover conditions by linearly increasing average temperature with depth $\left(2{ }^{\circ} \mathrm{C} / \mathrm{m}\right)$ in covers to account for the effects of elevated temperatures of underlying waste (Yeşiller et al. 2008). Thermal properties of the covers were obtained from Yeşiller et al. (2008) and the properties of the insulating materials were inferred from Benson et al. (1996) and van Donk and Tollner (2000).

Results of the parametric study are presented in Fig. 12. Results are provided for a typical compacted clay cover with no overlying insulating material $\left(\alpha=8 \times 10^{-7} \mathrm{~m}^{2} / \mathrm{s}\right)$ and two insulating materials representing limiting thermal properties $(\alpha=1$ $\times 10^{-7}$ and $1 \times 10^{-8} \mathrm{~m}^{2} / \mathrm{s}$ ) in Fig. 12(a). Climatic conditions for Alaska with the coldest air temperatures and maximum seasonal cover temperature differential (Table 2) were used in the analysis provided in Fig. 12(a). The effects of climatic conditions on an insulating material with a thermal diffusivity of $1 \times 10^{-7} \mathrm{~m}^{2} / \mathrm{s}$ are presented in Fig. 12(b). The use of insulating materials decreased the range of temperature variations in comparison to uninsulated conditions for variable climates. The decrease in temperature ranges was inversely proportional to thermal diffu-
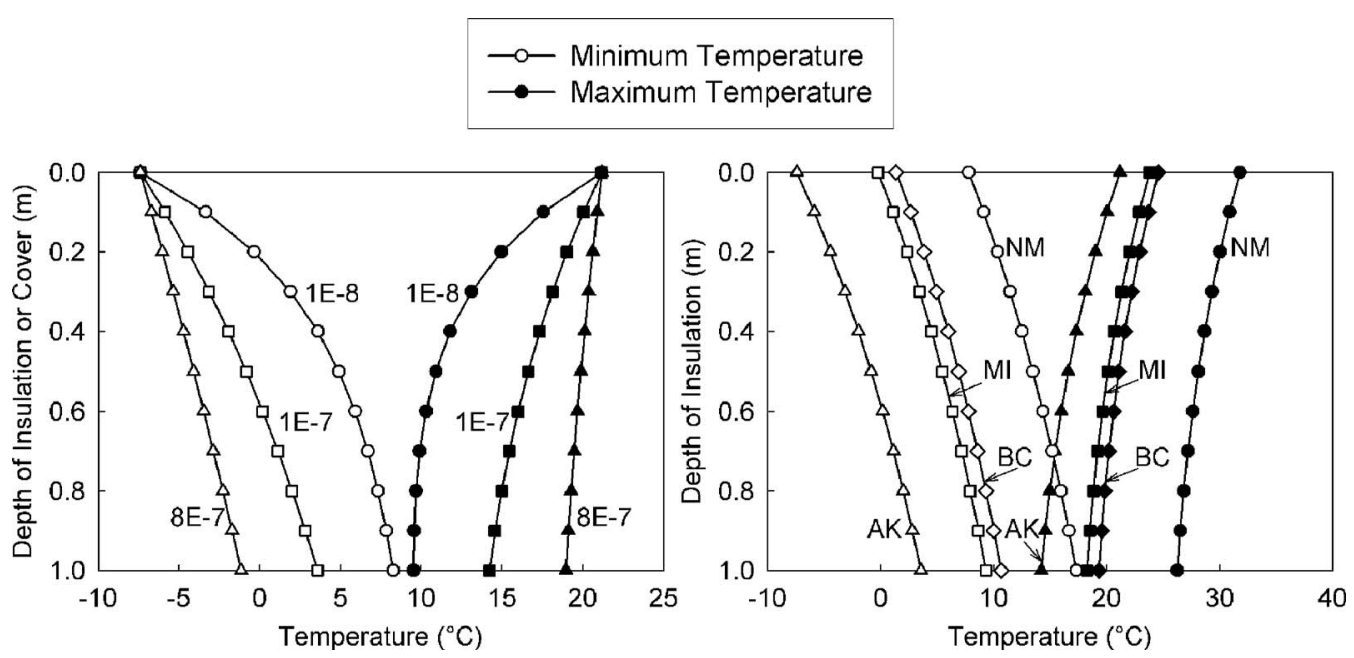

Fig. 12. Results of parametric investigation of insulating materials: (a) insulation; (b) climate 
sivity. The plots in Fig. 12 can be used in the design of insulating layers for temperature control in covers for similar material properties and climatic conditions. A similar analysis was conducted for exposed liners where the lower boundary was set equal to mean annual earth temperature (using conventional earth temperature theory) instead of the $2{ }^{\circ} \mathrm{C} / \mathrm{m}$ increase in temperature with depth used for the cover analysis. The resulting trends were similar to Fig. 12, with the exception that the envelopes were symmetrical about the mean annual earth temperature for the exposed liners.

\section{Conclusions}

Long-term spatial and temporal variations of temperatures have been investigated in covers, wastes, and bottom liner systems at four landfills located in different climatic regions: Alaska, British Columbia, Michigan, and New Mexico. Waste ages investigated ranged from under 1 year to more than 38 years. Effects of climatic and operational conditions on the temperature distributions were determined. Variations of temperatures with decomposition stages of wastes also were investigated. Analysis was conducted for control of temperature variations in covers and exposed liners. The main conclusions of this extensive investigation are provided below:

- Determination of temperatures using Type $\mathrm{K}$ thermocouples in flexible sensor arrays within well-sealed pathways has been demonstrated to be effective for landfill environments.

- The characteristic shape of waste temperature versus depth relationships consists of a convex temperature profile with maximum temperatures observed at central locations within the middle third fraction of the depth of the waste mass. Lower temperatures and trends similar to seasonal air temperature variations were observed above the central zone and in the covers, respectively. Temperatures near the base of the cells and in the liner systems were relatively steady and elevated above mean annual earth temperature, yet were below the maximum values in the central zones.

- The location of the maximum temperatures/heat gain is affected by waste placement temperature as well as by heat generation and dissipation. Sustained concave temperature profiles were observed for waste placement in cold temperatures.

- In British Columbia, temperature increases occurred for multiple years and then dissipated for tens of years. High waste moisture conditions resulted in rapid temperature increases. Longer periods of temperature increase were observed at the other sites, where temperatures continue to increase subsequent to approximately a decade since waste placement.

- The time-averaged waste temperatures were 0.9-33.0, 13.149.2, 14.8-55.6, and $20.5-33.6^{\circ} \mathrm{C}$ in Alaska, British Columbia, Michigan, and New Mexico, respectively.

- The maximum heat gain in wastes was observed in Michigan due to coupled high precipitation/moisture conditions and high waste density, whereas the lowest differential was observed in New Mexico due to the dry climate and low waste density.

- The highest heat generation (i.e., energy) and fastest heat gain (i.e., rate of temperature change) were observed in British Columbia due to enhanced microbial activity associated with high precipitation and wet wastes. However, the highest heat gain (i.e., magnitude of temperature change) did not occur at this site due to the coupled comparatively high heat capacity and low dry density of these wet wastes.

- Higher temperatures, temperature increases, and heat gain oc- curred during anaerobic decomposition of wastes than under aerobic conditions.

- A parametric study indicated that use of insulating materials over covers decreased the range of temperature variations compared to uninsulated conditions for prevention of frost penetration or desiccation and for optimum methane oxidation.

- Overall, the data and analyses presented in this paper can be used to establish realistic service conditions for landfill systems (including covers, wastes, and liners) for determining engineering performance.

\section{Acknowledgments}

This study was supported by the National Science Foundation (GOALI Grant No. CMS-9813248, SGER Grant No. CMS0301032, and a 2004 AAAS/NSF WISC Grant). Assistance of the partner landfills (Sauk Trail Hills Development, Corralitos Regional Landfill, Anchorage Regional Landfill, and Vancouver Landfill) is greatly appreciated. Dr. Wei-Lien Liu assisted with the field work and analyses.

\section{References}

Attal, A., Akunna, J., Camacho, P., Salmon, P., and Paris, I. (1992). "Anaerobic degradation of municipal wastes in landfill." Water Sci. Technol., 25(7), 243-253.

August, H., Holzlohner, U., and Meggyes, T., eds. (1997). Advanced landfill liner systems, Thomas Telford, London.

Barone, F. S., Costa, J. M. A., and Ciardullo, L. (2000). "Temperatures at the base of a municipal solid waste landfill." Proc., 6th Environmental Engineering Specialty Conf. of the CSCE, Candian Society for Civil Engineering, Ont., Canada, 41-48.

Benson, C. H., Olson, M. A., and Bergstrom, W. R. (1996). "Temperatures of insulated landfill liner." Transp. Res. Rec., 1534, 24-31.

Benson, C. H., and Othman, M. A. (1993). "Hydraulic conductivity of compacted clay frozen and thawed in situ." J. Geotech. Engrg., 121(1), 69-79.

Boeckx, P., Van Cleemput, O., and Villaralvo, I. (1996). "Methane emission from a landfill and the methane oxidising capacity of its covering soil." Soil Biol. Biochem., 28(10-11), 1397-1405.

Börjesson, G., Chanton, J., and Svensson, B. H. (2001). "Methane oxidation in two Swedish landfill covers measured with carbon-13 to carbon-12 isotope ratios." J. Environ. Qual., 30(2), 369-376.

Carslaw, H. S., and Jaeger, J. C. (1959). Conduction of heat in solids, 2nd Ed., Oxford University Press, New York.

Christophersen, M., Kjeldsen, P., Holst, H., and Chanton, J. (2001). "Lateral gas transport in soil adjacent to an old landfill: Factors governing emissions and methane oxidation." Waste Manage. Res., 19, 595612.

Dach, J., and Jager, J. (1995). "Prediction of gas and temperature with the disposal of pretreated residential waste." Proc., Sardinia 1995, 5th Int. Waste Management and Landfill Symp., T. H. Christensen, R. Cossu, and R. Stegmann, eds., Vol. I, CISA, Italy, 665-677.

DeWalle, F. B., Chian, E. S. K., and Hammerberg, E. (1978). "Gas production from solid waste in landfills." J. Envir. Engrg. Div., 104(3), 415-432.

Döll, P. (1997). "Desiccation below mineral liners with heat production." J. Geotech. Geoenviron. Eng., 123(11), 1001-1009.

e-CFR. (2009). "40 CFR, Parts 257 and 258." Electronic Code of Federal Regulations, 〈http://ecfr.gpoaccess.gov〉 (Aug. 13, 2009).

El-Fadel, M., Findikakis, A. N., and Leckie, J. O. (1996). "Numerical modeling of generation and transport of gas and heat in landfills I. Model formulation." Waste Manage. Res., 14(5), 483-504. 
Farquhar, G. J., and Rovers, F. A. (1973). "Gas production during refuse decomposition.” Water, Air, Soil Pollut., 2, 483-495.

Fleming, I. R., Rowe, R. K., and Cullimore, D. R. (1999). "Field observation of clogging in a landfill leachate collection system." Can. Geotech. J., 36(4), 685-707.

Gartung, E., Mullner, B., and Defregger, F. (1999). "Performance of compacted clay liners at the base of municipal landfills: The Bavarian experience." Proc., Sardinia 1999, 7th Int. Waste Management and Landfill Symp., T. H. Christensen, R. Cossu, and R. Stegmann, eds., Vol. III, CISA, Italy, 31-38.

Han, B., Imhoff, P. T., and Yazdani, R. (2007). "Field application of partitioning gas tracer test for measuring water in a bioreactor landfill." Environ. Sci. Technol., 41(1), 277-283.

Hanson, J. L., Liu, W.-L., and Yesiller, N. (2008). "Analytical and numerical methodology for modeling temperatures in landfills." Geotechnics of waste management and remediation, ASCE GSP No. 177, M. V. Khire, A. N. Alshawabkeh, and K. R. Reddy, eds., ASCE, Reston, Va., 24-31.

Hanson, J. L., Yesiller, N., and Kendall, L. A. (2005). "Integrated temperature and gas analysis at a municipal solid waste landfill." Proc., 16th Int. Conf. on Soil Mechanics and Geotechnical Engineering, Geotechnology in Harmony with the Global Environment, Millpress Science, Rotterdam, The Netherlands, 4, 2265-2268.

Hartz, K. E., Klink, R. E., and Ham, R. K. (1982). "Temperature effects: Methane generation from landfill samples." J. Envir. Engrg. Div., 108(4), 629-638.

Koerner, G. R. (2001). "In situ temperature monitoring of geosynthetics used in a landfill." Geotech. Fabr. Rep., 19(4), 12-13.

Koerner, G. R., and Koerner, R. M. (2006). "Long-term temperature monitoring of geomembranes at dry and wet landfills." Geotext. Geomembr., 24, 72-77.

Lamothe, D., and Edgers, L. (1994). "The effects of environmental parameters on the laboratory compression of refuse." Proc., 17th Int. Madison Waste Conf., Dept. of Engineering Professional Development, University of Wisconsin, Madison, Wis., 592-604.

Landsberg, H. E., Lippmann, H., Paffen, K. H., and Troll, C. (1966). World maps of climatology, 3rd Ed., E. Rodenwaldt and H. J. Jusatz, eds., Springer-Verlag, Berlin.

Lefebvre, X., Lanini, S., and Houi, D. (2000). "The role of aerobic activity on refuse temperature rise: I. Landfill experimental study." Waste Manage. Res., 18(5), 444-452.

Mata-Alvarez, J., and Martinez-Viturtia, A. (1986). "Laboratory simulation of municipal solid waste fermentation with leachate recycle." $J$. Chem. Technol. Biotechnol., 36(12), 547-556.

Meteorological Service of Canada (MSC). (2007). "Climate database." 〈http://www.msc-smc.ec.gc.ca/contents_e.html〉 (Sept. 23, 2007).

National Climatic Data Center (NCDC). (2006). "Climate database." $\langle$ http://www.ncdc.noaa.gov/〉 (Sept. 15, 2006).

Oak Ridge National Laboratory (ORNL). (1981). "Regional analysis of ground and above-ground climate." Oak Ridge National Laboratory
Rep. No. ORNL/Sub-81/40451/1, U.S. Dept. of Energy.

Oettle, N. K., Hanson, J. L., and Yesiller, N. (2008). "Determination of cover surface temperature for MSW landfills." Proc., 2008 Global Waste Management Symp., Penton Media, New York, 1-7.

Rees, J. F. (1980a). "The fate of carbon compounds in the landfill disposal of organic matter." J. Chem. Technol. Biotechnol., 30(4), 161175.

Rees, J. F. (1980b). "Optimisation of methane production and refuse decomposition in landfills by temperature control." J. Chem. Technol. Biotechnol., 30(8), 458-465.

Rowe, R. K. (1998). "Geosynthetics and the minimization of contaminant migration through barrier systems beneath solid waste." Proc., 6th Int. Conf. on Geosynthetics, R. K. Rowe, ed., Vol. I, IFAI, Atlanta, Ga., 27-102.

Rowe, R. K. (2005). "Long-term performance of containment barrier systems." Geotechnique, 55(9), 631-678.

Southen, J. M., and Rowe, R. K. (2005). "Laboratory investigation of geosynthetic clay liner desiccation in a composite liner subjected to thermal gradients." J. Geotech. Geoenviron. Eng., 131(7), 925-935.

Streese-Kleeberg, J., and Stegmann, R. (2008). "Biofiltration of landfill gas methane with active ventilation." Proc., 2008 Global Waste Management Symp., Penton Media, New York, 1-10.

Tchobanoglous, G., Theisen, H., and Vigil, S. A. (1993). Integrated solid waste management: Engineering principles and management issues, McGraw-Hill, New York.

Townsend, T. G., Miller, W. L., Lee, H. J., and Earle, J. F. K. (1996). "Acceleration of landfill stabilization using leachate recycle." J. Environ. Eng., 122(4), 263-268.

van Donk, S. J., and Tollner, E. W. (2000). "Apparent thermal conductivity of mulch materials exposed to forced convection." Trans. ASAE, 43(5), 1117-1127.

Yeşiller, N., Hanson, J. L., and Liu, W.-L. (2005). "Heat generation in municipal solid waste landfills." J. Geotech. Geoenviron. Eng., 131(11), 1330-1344.

Yeşiller, N., Hanson, J. L., Oettle, N. K., and Liu, W.-L. (2008). "Thermal analysis of cover systems in municipal solid waste landfills." J. Geotech. Geoenviron. Eng., 134(11), 1655-1664.

Yeşiller, N., and Hanson, J. L. (2003). "Analysis of temperatures at a municipal solid waste landfill." Proc., Sardinia 2003, 9th Int. Waste Management and Landfill Symp., T. H. Christensen, R. Cossu, and R. Stegmann, eds., CISA, Italy.

Yoshida, H., and Rowe, R. K. (2003). "Consideration of landfill liner temperature." Proc., Sardinia 2003, 9th Int. Waste Management and Landfill Symp., T. H. Christensen , R. Cossu, and R. Stegmann, eds., CISA, Italy.

Zanetti, M. C., Manna, L., and Genon, G. (1997). "Biogas production evaluation by means of thermal balances." Proc., Sardinia 1997, 6th Int. Waste Management and Landfill Symp., T. H. Christensen, R. Cossu, and R. Stegmann, eds., Vol. II, CISA, Italy, 523-531. 